\title{
An exploration of the Andai dance form (from the Horqin area of Inner Mongolia) from a dance/movement therapy perspective.
}

\section{从舞蹈动作治疗角度探索安代舞蹈 ( 中国内蒙古科尔沁地区 )}

\author{
Sharina \\ 莎日娜 \\ China Women's University, China
}

\begin{abstract}
Andai is a unique folk dance in Horqin of Inner Mongolia in China, and is related to shamanistic fertility worship observed by the Mongolian tribe in Horqin. The original Andai is a complete religious rite which includes such activities as therapy, prayer, singing and dancing. Even today on the Horqin Grassland, there are still widespread traditions of treating diseases both of unmarried women with psychosis and of infertile married women through Shamanic Andai dancing. However, as this time-honored Andai ritual has moved into the twenty-first century, it has already slipped the leash of religious thoughts and has been given new connotations - developing into a form of folk art for a new era and appearing as a significant physical training method for the Horqin people. As a researcher of the art of Mongolian dance, the author of this article has a deep passion for Andai. The jumping and stamping posture, the flying silk and the distance song of Andai are deeply attractive elements. This paper places Andai, which has passed from one generation of Mongolian people to the next, within the vision of modern frontier disciplines, namely Dance Movement Therapy. Through Dance Movement Therapy, Laban Movement Analysis (LMA) theories and methods, this paper also analyzes the forms and functions in Andai ceremony - illustrating not only the artistic features of mysterious religious thought and rich aesthetics of dance, but also highlighting Andai's scientific and practical applications. Taking this case as an example, this paper aims to explore both the rich heritage and developmental momentum of this ethnic Chinese Folk Dance.
\end{abstract}

Keywords: Andai, Dance/Movement Therapy, movement metaphor, collective empathy, Integrative Treatments.

\section{摘要}

安代是中国内蒙古科尔沁地区特有的萨满教仪式舞蹈。安代与科尔沁部落蒙古人所信仰 的萨满教生育崇拜有关。原始的安代是包括治疗、祈祷、歌唱、舞蹈等众多环节的完整 宗教仪式。科尔沁草原上至今流传着由萨满通过安代仪式舞蹈为患有精神 疾病的未婚 女子或不孕的已婚妇女治疗疾病的传统。古老的安代走到今天，已经摆脱了宗教思想的 束缚，被人们赋予新的内涵，发展成为新时代的民间艺术和科尔沁人们强身健体的重要 手段。笔者身为蒙古族舞蹈艺术研究者，对安代有着深厚的感情。安代腾踏跳跃的舞 
姿，飞扬的绸布、悠远的歌声，深深吸引着笔者。本文将蒙古族世代传承的安代置于现 代前沿学科一一舞动治疗视域中，通过舞动治疗、拉班动作分析(LMA)的相关理论和方 法、分析安代仪式中形态、功能等，揭示安代除神秘的宗教思想、丰富的舞蹈美学等艺 术特征外，其所蕴含的科学性、合理性，并希望以此为个案，探究中国少数民族民间舞 蹈传承的意义和发展的新动力。

\section{关键词: 安代, 舞动治疗，动作隐喻，集体共情，综合治疗手段}

Andai is a unique Shamanic dance art particular to the Horqin area in the east of the Mongolian Grassland. A primitive shamanistic ritual integrally linked to the worship of fertility, the primitive Andai - a complete religious ritual including such segments as praying, singing, dancing and treating - varies from the current artistic creation we see on the stage. The Andai art, which can be traced back to ancient times, now has a restored freshness and vitality again in the twenty-first century. Free from the bondage of religious ideas, Andai has been given new connotations and has become a significant tool for the development of folk art and for body-building of the Horqin people. The dance vocabulary of Andai has been organized into Andai gymnastics and has been popularized in a number of grassroots areas - spreading to middle schools, primary schools and communities. As time has passed, the vocabulary of Andai dance has fluctuated somewhat, but its core therapeutic form, used by the Mongolian people of the Horqin area, has maintained the basic functions of Andai dance. Earlier research undertaken into Andai focuses mostly on aspects of dance type and dance vocabulary; with the development of applied theory and practice of dance, however, dance therapy now has a domestic application to this most ancient ritual. The goal and process of Andai ritual, together with the costume, musical instruments, song and the concept of healing dance, shares many points of coherence with the theory and method of art therapy. This article will include the dance in Andai ritual as its main object of study, but will also focus on an analysis of the collective empathy and movement metaphor embodied in Andai dance under the aspect of dance therapy.

\section{The Andai ritual - its mythic origins and therapeutic applications}

To fully explore and understand the origins of Andai dance, we must identify several mythic stories that underscore its application and treatment of female infertility and psychological illness. The first of these tales also explains some of the guiding principles of Andai dance in its use of ritualised space and song for healing purposes.

The tale called "Uruga Andai" focuses on a girl who, long ago, lived with her father on the Gorlos Hala. One day she suddenly became ill; she would neither eat nor drink and laughed and cried by turns. Her father, burning with anxiety, took his daughter to see many doctors, but they could do nothing for her and there was no sign of her making a recovery. Distraught and helpless, the father had no choice but to place his daughter on a herdsman's wooden cart and take his daughter to a faraway Mongolian town in the 
hope that he would find someone who could to cure his daughter of this mysterious malady. However, when they arrived at the town of Kulun, the axle of the cart broke. Seeing that his daughter's condition had deteriorated, the father could do little except wander around the broken cart, looking up to the sky as he sang a song to express his profound grief. Local people heard his lamentation and joined him as he walked around the cart, weeping and singing. At this point, to everyone's surprise, the dying daughter rose quietly, got off the cart and joined her father and the townspeople as they moved around the cart singing and swinging their arms. Sweating after her exertions, the girl was miraculously cured.

Later, people began to use Andai as a means of curing similar diseases in young women by dancing around them and singing encouraging sentences.

In another tale, we are told of a newly married woman who became depressed because of her inability to bear children. On hearing the singing of a group of dancers, she felt so happy that she joined their dance until she was dripping with sweat. Soon after this activity she found she had become pregnant. Both of these early stories infer that Andai actually refers to the lovesickness or (absent-minded disease) of unmarried women and the infertility of married women. Specific statistics provided by folk artists indicate that it is women between the ages of 18 and 25 who suffer such debilitating conditions. No examples exist either below or beyond this age range - the age when a woman is at her most fertile.

The "Ada" Andai is a tale that refers to women to being possessed by either ghosts or a devil. Long ago, we are told, far in the northeast, there lived three princesses: Zhalandugui, Wusenhailuoer, and Elegexila. Possessed of magical properties, these three princesses roamed widely, gliding through the air. When their shadows rested on the bodies of girls and women who lived on the ground, those girls and women became ill with unknown diseases that proved difficult to cure. In order to save these earthly women from such suffering, the Buddha Sakyamuni taught the shamans a technique for curing this disease. As each patient sat, beating a drum and a small cymbal, the Suhai shaman and Gadsau (the singer) would sing and dance around her until she had recovered. In the early days, the core emphasis of this Andai cure was primarily vocal - hence the title of "Sing Andai".

Another ancient tale identifies a similar ailment and couples it even more clearly with a singing cure. Some 1200 years ago, there was a singer named Andaiqin who could, by performing the Sing Andai, attach the Andai ghost to the body of a human being and drive that person insane. Andaiqin could also reverse the process and effect a complete recovery by singing. When Andaiqin died, only the shaman of the Horqin area could cure this kind of disease. This story emphasised that the disease known as Andai came about as a result of ghostly possession; contact with some unknown force from outside the human body led to this disease.

Reading these mythic stories, we can see that the goal of the Andai ritual was and still is to cure various physical and psychological ailments. To this end, the ritual of Andai has been equipped with certain functionality. Dance movements embedded in this Andai ritual are echoed within the culture, individuality and psychological state of the Horqin area and have clearly been explored and utilised as dance/movement therapy. 


\section{Collective Empathy in Andai Ritual}

It is important to begin with an exploration of the structure of Andai ritual. The author has explored the structure of Andai ritual based on both field investigations and literary reviews. The ancient Andai ritual is structured in the following way:

Preparation: on kraft paper, a shaman draws a dog - king of a dog country - holding a giant horse on which three white glede princess are sitting. A pair of shoes is fastened between two trees with strings. Below a house, bundled with straw and paper, a hole is dug.

Praising the whip: the shaman holds the "Five Glede Whip" on each hand with a treasured sword or a single drum, and two people enter the stage. The empress sits on the chair and is served by two persons playing the drum and small cymbal constantly while the singer is singing a song named "praising the whip".

Console: If singing the song of "Hezhulie" is not effective, then the singer should change to other consoling songs such as "Bore".

Praising the Tea: The singer sings the song of "Praising the Tea" and lets the patient drink the tea.

Climax: After drinking the tea, the patient becomes energetic and dances slightly. The speed of movement begins to accelerate and the mood of the audience lifts. As the dancing and singing move towards the climax, the singer starts to sing the song named "Dulengzhang".

Harnessing the house: the shaman enters this area after the patient and participants are exhausted with dancing and singing. The patient is led by the shaman and the singer to the front of the paper house to sing the song named "Elengwa" and to harness the house.

Finish: Led by the shaman, the patient throws herself on the paper house, sends the portrayal to the front of the house and burns it together with the paper house.

\section{The process of the Andai at the middle stage}

Preparation: it is the shaman who, together with the relatives and friends of the patient, decides the time and scale of this ritual. The time chosen is generally between the period of summer hoeing and the autumn harvest. Seven days comprise a short timescale, twenty-one days make up a longer timescale, and forty days may be the longest. Suitable ground is then selected with a measurement of twenty-one double step circumference and to a depth of some three feet. The space is paved with weed or horse dung, covered with wet soil and then trampled for the sake of increasing the elasticity of the ground. Last but not least, an axel is erected at the center of the ground, and set into the ground.

Begin: The patient enters the ground supported by two handsome ephebes (young men) and then sits on the bench beside the axle with her hair covering the front of her face and her palms placed together. She then picks up a joss stick. All the people form a circle while the shaman - together with the singer - enters the ground praising the whip and consoling. The singer switches his right hand with his left hand held akimbo. The patient is given a sign to raise her head or switch her hands simultaneously, tracing a path from outside of the body to the middle of her legs. Meanwhile, the singer examines the lacuna of hairs carefully asking for the source of the disease, keeping singing all the while. 
Climax: The patient starts to speak and dance with the movement of the shaman. Meanwhile, the singer keeps singing and an increasing number of people start to join in at various stages, creating antiphonal music with alternate musical phrases. The people stamp and step hand in hand, drawing the patient with them. The singer slips in and out of the crowd following the patient.

Finish: The paper house and paper man are burned. A triangular hole is dug at a three-way intersection and, within that, five cereals and whatever the patient needs are placed within it. (Bai Cuiying, 2005)

Led by the shaman - with people dancing and guiding the patient to dance - the patient is cured. This process can be closely linked to key elements of dance/movement therapy; kinesthesis establishes collective empathy amongst the participants establishing and developing relationships. In the Andai ritual, it is the shaman who is the leader, and his movement (with its religious roots) produces the stimulus that evokes kinesthetic experiences in both the patient and people surrounding them. People are led by the holy song and by the movement of the shaman's stamp and dance. The collective empathy of kinesthesia feeds back into the patient's experience as she joins in the Andai ritual; she becomes gradually infected by the environment of the field dominated by collective consciousness.

As has been mentioned earlier, the Horqin shamanic dance belongs to the nonvisualized dance category - the circular organisation of movement echoing a godly presence. The circle is the first spatial concept mastered by early humans prior to codified linear movement. "This circle may use a person or an object as the center that its power either can radiate to the people around or can be reflected from the surrounded people."(Curt Sachs, 1992) The original shamanic dance was mostly in the form of "poussette" - directly linked to human anthropoidal development. Susanne K Langer believes that the poussette and round dance (the chosen forms of dance) were irrelevant to the spontaneous jump, since they were performing holy functions - that is, distinguishing the holy kingdom from mundane world. Such dance - created and contained within a circular form - centered round a sacrificial altar or other similar construct and within in this magic circle of dance, all vigor and energy could be released. (Susanne K. Langer, 1986) Such directional emphasis of circular movement in a prescribed space guides the energy and motion of the dancers within the circle and increases the gravitational field of direction towards the centre of the circle.

The importance of the circle as a functioning space for the Andai ritual has clear application in the field of dance/movement therapy. Marian Chace, the pioneer and founder of dance/movement therapy, believes in the idea of "dance for communication" and explains how non-verbal body movement can be effectively used in the treatment of patients with psychiatric illnesses. (Fran Levy, 2005) In her "Chace Technique", she recommends that healers should form circles during both the warm-up and close-out stage of treatment. She sees this as an effective way of establishing a coherent structure within groups and believes that each individual within such a circle (including the therapist) gains feelings of trust and of both giving and receiving support. Circular dance can also create a strong sense of collective empathy and group sharing. Within the Andai ritual, it is the shaman who plays a dominant 
part within the circle, controlling the rhythms and emotional expressions of the entire ritual. He uses a belled whip to lead people in dance, and those who follow the shaman's motions share their own repeated movements with others as they sing pulsating folk songs. An empathetic response to such rhythmic movement and song becomes a therapeutic combination in itself; such a powerful collective dance can effectively create emotional experiences in patients who are the focus of such activity and treatment.

Such a field of trust is established through a sense of collective empathy and, with an infective unified rhythm and the support of safe props such as shawls and longsleeved garments, the Andai ritual transfers and dispatches unhealthy and harmful emotions through the circle and beyond its circumference. There are several hierarchical circles within this Andai ritual: with the patient at the very core of the activity, the shaman dances around them in order to drive away the devil from their bodies whilst additional participants dance around the shaman in order to increase his power and effect a full recovery for the patient.

\section{Movement Metaphor in the Andai Ritual}

"A metaphor is a symbolic representation. A bodily metaphor is a symbolic representative expressed in the form of bodily posture or movement." (Linni J, 1985) In dance/ movement therapy, the relationship between movement and psychology runs deep; movement often reflects personality. Such changes in aspects of movement, therefore, can influence the function as a whole, and so movement takes on a symbolic function in indicating subconscious processes. (Li Weixiao, 2014)

Physical movement can be perceived as the externalized expression of inner psychological processes, so both the observation and experience of bodily movement are direct and effective ways to communicate with psychological states. The acknowledgement and application of movement as metaphor allows us to facilitate the improvement of original psychological states based on such information as an individual's own pattern of movement and their physical responses to those around them. Movement metaphor is one of the essential tools of dance/movement therapy.

Professor Shaun McNiff explains in "The Arts and Psychotherapy" that the expressive art therapist is one who treats the characteristics of his clients and their art work not as intellectually defined perceivable properties of body, voice, and behavior and art but as a product of expressive manifestations of the person's state of mind. (Shaun McNiff, 1979) We find an entirely harmonious and complementary view expressed within LMA; the movements of human body contain the themes of duality - of function and expression. It is expressive movement that reveals both the human body's intrinsic impulsion and reason of movement.

Movement metaphors have obvious applications in both the fields of primitive and religious art where movement becomes not only a perceived action but the symbolic language of primitive thought. The relationship between a fantasy expressed in symbolic form and a true object is both direct and identical. Such duality is expressed in the shamanic dance at the heart of the Andai ritual - a ritual clearly influenced by the prim- 
itive religion of the Horqin. The author has selected an example of a dance movement with a fixed pattern that regularly occurs within the Andai ritual.

\subsection{The Andai Ritual: Stamping}

To place a foot on the ground with focus and with energy is not only recognised as a movement specific to anthropoid forms but can also be seen a form of emotional outlet for primitive human emotions. This simple movement is easily controlled by the brain and is a natural, instinctive human movement that satisfies the need to vent energy. When an individual repeats such a movement, a regular rhythmic pattern occurs; when this pattern of movement is repeated within a group setting, a primitive awareness of uniform movement comes into existence. It is by this process of continuous stamping that humans have improved the quality of their bodies, have asserted the development of individual and have established a sense of collective behavior.

The action of repeated rhythmic stamping actions plays a key role in the Mongolian shamanic dance. According to a secret history of the Mongols, when Hotula was proposed as Khan the Mongolian tribe danced and prayed for him. The author found a picture on the cliff painting in the Shanyin Mountains of Inner Mongolia which vividly depicted such basic dance movements as would have been used in ancient times. In this cliff painting, dancers wore prominent headwear, waistbands and long gowns and were depicted as being slightly bent at one leg with the other elevated. The inference - and natural gravitational pull - would suggest that they were about to stamp.

Stamping rhythmically is a consistent feature in Andai dance and participants in the ritual are guided by its unifying rhythm. Those people who are judged to be either insane or drunk are not allowed to participate in the Andai dance, since the disharmonious rhythm they create may disturb the will of the shaman and such a breaking of rhythm might result in the failure of the ceremony. The Andai ritual, in its form as dance art, recognizes that both tune and rhythm are of paramount importance. Participants must conform to the regular pattern of stamping. A clapping of hands - to reinforce the established rhythmic pattern created by stamping - can also required. During the ritual, if a participant's boot is broken and their foot is swollen because of stamping, they will move to the center of the circle to increase the sense of rhythm by shouting.

The action of stamping - which is an instinctual human response - has been absorbed and inherited by Andai. If we explore this physical action more deeply and express the texture of the stamping action through the vocabulary of Laban Effort, we can understand that the texture of the stamping motion is rectilinear with direct attention. The movement itself is quick; all energy gathers in the legs which are stamped quickly on the ground, releasing directional, focused energy and indicating a gesture of unbridled freedom. Both the texture and metaphor of this movement are closely connected here. The shamanic belief is that people become sick because something bad has entered their body or their spirit has been controlled by devils. This means that expulsion is at the crux of their healing - driving away the bad things which have made their patient ill.

It is difficult, at this point, to ignore elements of witchcraft which permeate the Andai ritual; it is the shaman who takes the central role in this ritual and who, with the assistance of participants who sing and dance around him, seeks to drive the devil from 
their patient's body and restore them to health. According to the "multi-layered universe" of Mongolian Shamanism, devils come from underground and seek to harm people but they are afraid of people who possess powers which do not exist in the natural world those powers created by human voices and musical instruments.

I referred earlier in this article to the careful preparation of a site for 'Da-Andai' ritual in Kulunqi. The rhythmic sound produced by such unified stamping on such a surface would produce a much greater resonance than simply stamping on un-prepared earth and would frighten any devil who was present in the patients' body, forcing it to leave its host. The action of stamping is a vigorous one, and such regular movement has proved to be another effective (if often unintentional) cure for some diseases. During the Andai ritual, the shaman encourages his patient to stamp hard, throw their head back and wave their hands dramatically. This aerobic activity allows patients exercise their muscles sweat profusely and echoes closely such activity used in current dance/movement therapy.

According to Laban Effort, the action of stamping combines elements of speed, weight and direction. If we combine the application of such effort in dance and movement therapy (together with the principle of supplying the shortage), we can see that the effort of stamping the foot in such a way is contrary to the typical effort of depressed patients, which can best be described as indirect, slight and persistent. Under the combined emotional stimuli produced by the collective stamping and resounding singing which surround them during the Andai ritual, women who have developed psychological illnesses as a result of infertility have found not only relief from their pain but an easing of their anxiety and frustration by giving vent to their innermost feelings in such a highly physical way.

Although the Andai ritual does not directly address elements of sexual behavior in their treatment, the stamping movement so integral to the ritual has often remedied incidences of infertility. It may be that the patients, participants and even the shaman of the Horqin area are quite simply following to the ritual of this holy ceremony and the concomitant beliefs passed down from their ancestors rather than fully comprehending the crux of Andai as a therapy. Regardless, they have unintentionally enriched this most ancient of human movements.

\subsection{Shamanic musicianship: the role of the belled whip}

Musical instruments take on a deeply symbolic role in shamanism. The shaman enters the spiritual world using the power of musical instruments and battles with devils under the protection of these ritual implements which they also use as weapons. In the Andai ritual, musical instruments become the externalized form of the shamanic experience.

One of these instruments, the belled whip, is used throughout the Andai ritual and is the significant musical instrument identified with the shaman as he guides the route taken by dancers and leads the patient towards healing. The belled whip is some two feet long with two bells and two small bronze mirrors at its base. Its tassel is made of five silken strands of different colors entwined together. The shaman believed that the sound of the bell was not only an omen of the approach of gods, but also echoed the sound of violent storms and roaring waves which were heard during the battle between the sha- 
man and devil as he made his way to the spiritual world. The bronze mirror is the guardian of safety; its light gathered from the rays of both the moon and the sun aids the shaman as he seeks out the harmful devil who is concealed in darkness.

There are several metaphorical uses of the belled whip in shamanism: it can function as a drumstick and can also can be used as a whip as the shaman gallops galloping across the battlefield when he is in his altered mental state. The belled whip can be used as a vessel that allows the shaman to travel around both mountains and sea. It can also be used as a weapon used for repelling the devil. In the Mongolian language, a drumstick is called "Zhaxiguri" or "snake". Ancient shamans adored ferocious, large animals and in ancient Mongolian shamanism the snake was a symbol of exuberant male fertility. In the Snow Worship Ritual of Manchu shamanism, a god puppet named "Chuchukuo" is adored and worshipped and is represented in a circular ice engraving which looks like male genitalia surrounded by a snake. After the snow worship ritual, childless couples are required to consume the ice god puppet in order that they might acquire the rite of fertility from the god. The belled whip of Horqin Shamanism - a manifestation of this drumstick - is taken to have the same efficacy.

From the shamanic point of view, beating and touching patients with a musical instrument has strong symbolic significance. The act of touching and kneading an infertile patient during the Andai ritual is clearly linked to sexual intercourse. In "Heaven Father and Earth Mother" - a witchcraft dance of the Dong minority - a woman holds a drum head (symbolizing the cysthus - the female genital area) and a man holds a drumstick which symbolizes the male genital organ. As the woman and man dance together, the drumstick and the drum head rub and twist together, symbolizing sexual intercourse.

As I mentioned in an earlier description of the various stages of the Andai ritual, the ceremony begins when a patient is carried to the center of the transcribed circle with her hair covering her face. The shaman, leading the dance, has the belled whip in his right hand. With that right hand akimbo, he moves three times around the patient and then holds the belled whip above her head. This is to bring the patient to her senses. After witnessing some reaction from the patient, the shaman strikes the patient's teeth three times (this has been called "Big Teeth Boerpu") causing the patient to start and to make some slight movement. As the shaman raises the belled whip up, so the patient also raises her head to follow the arc of the whip. In making such a move, she sweeps her hair back from her face to fall behind her; now she has fully accepted the leadership of the shaman and will begin to dance under his command. Later in a dance between shaman and his patient, she will prostrate herself on the ground while the shaman attracts her attention and communicates with her by shaking the belled whip in front of her. Most of the content of this conversation between shaman and patient is that of enquiry and comfort and allows the woman to give vent to her inner anguish. If a shaman believes that a woman has been haunted by the devil, he will strike the ground a number of times with the belled whip as his patient rolls on the ground a corresponding number of times.

In ancient Andai ritual, the traditional belled whip was the musical instrument of the shamanic dance leader. As centuries have passed, however, the arcing swing of the belled whip has been echoed and enhanced by participants swinging their sleeves, 
handkerchiefs and gathered waistbands - all of which have contributed to the indispensable element of current Andai dance - their use of silk.

The vocabulary of Andai dance has transitioned from such simply delineated movements as "stamping and turning down" (in earlier times) to incorporating a more complex series of shoulder movements (constant elements of Mongolian dance) and including additional movements as "onrush forward", "step knee jump" and "brandish silk with two arms" which enhances the overall rhythmic experience of the ritual. Such an increase in complexity - and movement away from the more streamlined metaphorical movements of the belled whip - indicate an aesthetic appreciation and enhancement of the original ritualised moves embedded in the Andai ritual.

\section{Integrative treatment in the Andai ritual}

\subsection{The libretto}

There are many layers to the Andai ritual - not only the ritualised organisation of space, the progression through song and dance with specifically identified movements and props - but also the process of libretto gathering. This is a therapy based on the comprehensive method of musical drama and reflects the core beliefs of the shamanic ritual. Additionally, the pioneer of the subject of art therapy, Joseph Moreno, has given a very positive affirmation on this term. (Joseph Moreno, 1988).

The curative properties within the Andai ritual are expressed through movement, but, like all expressive art therapies, this treatment has drawn various artistic disciplines to it and embraced them as a creative whole. The shaman not only leads the patient and the crowd in rhythmic stamping movements, but also sings Andai songs which complement and enhance these rhythms. The lyrics of such songs usually reflect the natural world and the lives of the people and can also function on a metaphorical level. Such an example is quoted below:

If it's a sunny day and there's no cloud in the sky, how could the dew fall?

If there's no love since ancient times, how could the joyful songs exist...?

The scarlet sun is hanging over the sky; once the floating clouds come over, it will become an overcast day.

Marriage [without] following your heart is just like falling into abyss...

The pure white bird, with maculae on its chest...

Your comely body has disease in your heart.

Though a look of misery had lasted for years and covered your heart and lung, now your long cherished wish will be satisfied, and you are ensured with a clear mind. (Wurenqiqige, 2008)

This libretto of Andai song reflects elements of the natural world but also functions on a metaphorical level to explore the life experiences of those who sing them. Andai song, supplementing dance movements undertaken in the process of curing a patient, can sympathise with her current circumstances, stimulate her mood and induce an 
emotional response. Such songs, linked with hypnotic, rhythmically intense dance moves as part of the Andai ritual, contribute in no small way to a benign transformation of the patient.

\subsection{Site Layout}

The site layout of the Andai ritual is rich with an intense symbolic significance. In the process of arranging the field, the wheel of the leading vehicle of the patients' family which pulled the salt for the first time should stand at the center of the ground with a stumpage, or a golden pillar, which is tied with calico and has a hada or lantern, inserted behind. The author believed that this kind of decoration, which represented male genitalia, was influenced by what was primarily an agricultural civilization. Bo in the Horqin area believed that the Andai disease was actually a yin disease; as a result, only such methods as "treating yin disease by yang method" and "combining yin and yang" were adopted as effective treatments. The author believes that the symbolized site layout for the Andai ritual establishes a field of trust that, at the same time, provides the patient with visual associations heavy with sexual imagery. The circular formation, clearly established in Andai ritual, means that the emotion of patients can be safely released and accepted in this spatial arrangement.

\section{Conclusion}

In the cultural ecology of Chinese dance, minority folk dances similar to Andai - with their lengthy ethnic and cultural connotations and a striking combination of artistic expression and functionality (the treatment of specific diseases) - have brought dynamism and vigor to various ethic groupings. The ethnic Mongolian art of Andai, with its profound cultural connotations and its gradual metamorphosis over past centuries, has impressed the author with its energetic life vigor. The change from ancient to modern coda, from belief to truth, has deeply influenced the art of Andai, which, itself, has now moved from a mysterious religious ceremony to a popular form of entertainment in both rural and urban areas, When we observe minority folk dances (including the Mongolian Andai in China) from the perspective of dance therapy, we understand that the investigation of the art of dance allows us to further explore the ethnic and cultural connotations behind such an ancient ceremony. Additionally, using the growing science of dance therapy - which adopts the cultural contexts and body movement patterns identified by the Chinese - enables us to combine the therapeutic dance ceremony of Chinese ethnic minorities with western principles and methods of dance therapy.

\section{About the Author}

Sharina (莎日娜), $\mathrm{PhD}$, lecturer at China Women's University, the visiting scholar of University of California, Irvine. Research field: Chinese folk dance, Labanotation.

\section{References}

Cuiying, B. (2005). Internal archive of Zhelimumeng Culture Centre.

Langer, S.K. (1986). Feeling and Form. China: China Social Sciences Press. 218. 
Levy, F. (2005). Dance/Movement Therapy: A Healing Art. (Cai Peishan; Zhou Yu; Shen Yan, translation, 2014). China: Inspirees International Press, 23.

McNiff, S. (1979). From Shamanism To Art Therapy, Art Therapy, Vol.6,155-161.

Moreno, J.J. (1988). The Music Therapist: Creative Arts therapist and contemporary shaman, Art Psychotherapy, Vol.1.15.

Sachs, C. (1992). World History of the Dance: 52.

Silberman-Deihl, L.J. (1985). Treating Psychogenic Somatic Disorders Through Body Metaphor. American Journal of Dance.

Weixiao, L. (2014). The Origin of Dance/Movement Therapy, Beijing: China Light Industry Press, 43-45.

Shiwu, L. (2016). Commentary on the Study of Art Psychotherapy of Shamanism "Art Therapy", World Ethno-National Studies, Vol.1, 2016.

Wurenqiqige. (2008). Andai treatment of National Spirit interpretation of the ceremony Cultural Heritage. Vol.3, 2008. 